\title{
CLERKING AT THE SUPREME COURT OF CANADA ${ }^{\prime}$
}

\author{
MITCHELL McINNES, JANET BOLTON** \\ and NATALIE DERZKO $\cdots$
}

This article takes an in-depth look at the law clerks and the role they play at the Supreme Court of Canada. Such an examination both informs prospective clerks on the nature of the position and promotes a better general understanding of how the judicial process operates at this level.

The authors begin their analysis by looking at the history of the law clerks at the Supreme Court. Although the functions of the clerks have changed little since their introduction in 1968, the clerkship program has evolved with a changing Supreme Court, contributing to the institution's "coming of age."

The authors then shift their attention to examining the present clerkship program. The article first reveals the manner in which the clerks are selected by the Court. Using data collected by a questionnaire sent to clerks of the 1991-93 terms, the authors also attempt to convey, in a general way, some sense of the people who have served at the Court in recent years. Next, the major functions performed by the clerks are described. While the clerks do have a great deal of responsibility, the authors dispel much of the criticism directed at United States Supreme Court clerks by stating that the law clerks at the Supreme Court of Canada do not have an improper degree of authority.

The authors conclude that the clerking experience benefits both the clerks themselves and the procedures of the Court. As such, the law clerks are an entrenched and indispensable part of the judicial process at the Supreme Court of Canada.
Le présent article examine le secteur paraprofessionnel juridique et son róle au sein de la Cour suprême du Canada. Cette étude permet de mieux comprendre le fonctionnement du processus juridique à ce niveau et pourrait intéresser les personnes qui se destinent à faire carrière dans ce secteur.

Les auteurs commencent par étudier l'histoire de la profession à la Cour suprême. Bien que les fonctions du personnel aient peu changé depuis la création des postes en 1968, le programme de cléricature a changé en même temps que la Cour et témoigne de l'évolution de l'institution.

Les auteurs présentent ensuite le programme de cléricature actuellement en vigueur. Ils décrivent le processus de sélection du personnel qui, à l'instar de la sélection pratiquée dans le domaine sportif. tient compte à la fois de l'éducation institutionnelle et des traits de personnalité les plus appropriés. En s'inspirant d'un questionnaire envoyé au personnel des années 1991-93, les auteurs tentent d'établir le profil des personnes qui ont été employées par la Cour au cours des dernières années. L'article se termine par la description des tâches, qui inclut la préparation de différents documents juridiques. Bien que cette catégorie de personnel assume de nombreuses responsabilités, les auteurs réfutent les critiques habituellement adressées à la cour suprême des États-Unis en affirmant que les commis de la Cour suprême du Canada ne jouissent pas d'une autorité excessive.

Les auteurs concluent que l'expérience des commis profite à la fois aux intéressés et à la Cour. Ce secteur professionnel fait partie intégrante $d u$ processus juridique de la Cour suprême du Canada.

I The authors wish to thank Mr. Justice Major and Mr. Justice Sopinka for the encouragement they provided with respect to the writing of this article. As employees of the Court, law clerks are subject to a broad duty of confidentiality and must receive express consent before they can discuss publicly the knowledge that they acquire during their term of employment.

- Mitchell McInnes, B.A., LL.B. (Alberta), LL.M., Ph.D. (Cambridge), Clerk to Mr. Justice Major (1993-94), Lecturer, Deakin University, Geelong, Australia.

- Janet Bolton, B.A. (Toronto), LL.B./B.C.L. (McGill), Clerk to Mr. Justice Major (1993-94), Master of European Studies Candidate, College of Europe, Brugge, Belgium.

.. Natalie Derzko, B.Sc. (Toronto), LL.B. (Osgoode Hall), Clerk to Mr. Justice Sopinka (1993-94), LL.M. Candidate, Harvard Law School. 
TABLE OF CONTENTS

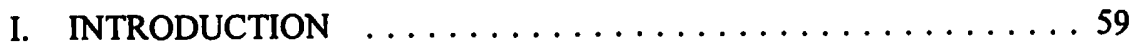

II. A HISTORY OF CLERKING AT THE

SUPREME COURT OF CANADA $\ldots \ldots \ldots \ldots \ldots \ldots \ldots 60$

III. THE CLERK SELECTION PROCESS $\ldots \ldots \ldots \ldots \ldots \ldots \ldots 63$

IV. A BIOGRAPHICAL SKETCH OF RECENT CLERKS $\ldots \ldots \ldots 65$

V. THE FUNCTIONS OF A LAW CLERK $\ldots \ldots \ldots \ldots \ldots \ldots 70$

A. LEAVE MEMORANDA $\ldots \ldots \ldots \ldots \ldots \ldots \ldots \ldots \ldots$

B. BENCH MEMORANDA $\ldots \ldots \ldots \ldots \ldots \ldots \ldots \ldots \ldots$

C. JUDGMENT WRITING $\ldots \ldots \ldots \ldots \ldots \ldots \ldots \ldots \ldots$

VI. THE CLERKING EXPERIENCE $\ldots \ldots \ldots \ldots \ldots \ldots \ldots \ldots 79$

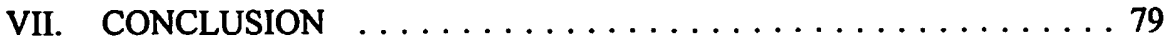

\section{INTRODUCTION}

From humble origins, ${ }^{2}$ the Supreme Court of Canada has evolved into one of the country's most prominent institutions. ${ }^{3}$ And yet, in many ways, it remains one of the least understood. Although the Justices have been increasingly willing to depart from the traditional rule of absolute secrecy, even within the legal community there remains considerable uncertainty regarding life at the Court. This uncertainty is particularly true with respect to the many people who work outside the public spotlight. The nine men and women on the bench are certainly the most important and visible members of the Court, but they do not act alone. This article will examine one group of individuals who assist in the judicial process at this level: the law clerks. ${ }^{4}$

The object of this article is twofold. On a general level, it is intended to further promote accessibility to the Supreme Court of Canada. The institution can only benefit from better public understanding; both lawyers and lay persons will feel a greater affinity with, and will have more confidence in, a Court which is known to function openly. Second, on a more specific level, the ensuing discussion is aimed at apprising prospective clerks of the nature of the position. Often, it is difficult for potential candidates to acquire such information. Very little has appeared in print. Moreover, while some Canadian law schools have a number of former clerks on faculty, the same

2 The Court's chequered past is described in J.G. Snell \& F. Vaughan, The Supreme Court of Canada: The History of the Institution (Toronto: University of Toronto Press, 1985) and I. Bushnell, The Captive Court: A Study of the Supreme Court of Canada (Montreal: McGillQueen's University Press, 1992).

3 Undoubtedly, a number of factors have contributed to the Court's increased Canadian stature. In recent years, however, the most significant is surely the introduction in 1982 of the Canadian Charter of Rights and Freedoms Part I of the Constitution Act, 1982, being Schedule B to the Canada Act 1982 (U.K.), 1982, c. 11 [hereinafter the Charter]. For better or worse, by forcing the judiciary into a more overtly political role, the Charter has placed the Supreme Court of Canada squarely under the public spotlight. The Court's decisions are now commonly the topic of comment and debate not only in the legal community, but also in the media and on the street.

4 Of course, the Supreme Court of Canada is not the only court to employ law clerks. However, the discussion that follows is necessarily limited to matters with which the authors have personal experience. 
is not true at all universities. Consequently, in many instances, students have no resource to which they can turn and, as a result, may be discouraged from applying. Obviously, this is an unfortunate situation. Some outstanding students are effectively deprived of the opportunity to enjoy a rewarding experience. Furthermore, the talent pool from which the judges select clerks is neither as diverse nor as strong as it could be.

The discussion will be divided into five parts. First, the history of law clerks at the Supreme Court of Canada will be examined. Second, the manner in which clerks are selected by the Court will be explained. Third, a composite biographical profile of recent clerks will be sketched. Fourth, the major functions performed by the clerks will be described. And finally, a few broad observations on the clerking experience as a whole will be offered. The type of material that will not be included in this paper also should be noted. Disappointment awaits readers who were hoping for a northern version of Bob Woodward and Scott Armstrong's 1979 bestseller, The Brethren. ${ }^{5}$ That controversial work, based largely on information disclosed by former United States Supreme Court law clerks, breached traditional rules of confidentiality regarding the work habits and personal attitudes of the judges, and the manner in which specific decisions were reached by the American Court. By contrast, the authors of this article will observe fully the duty of confidentiality to which they are subject.

\section{A HISTORY OF CLERKING AT THE SUPREME COURT OF CANADA}

While the United States Supreme Court has employed clerks since the 1880s, the history of clerking at the Supreme Court of Canada has been relatively short. ${ }^{6}$ Although proposals to hire clerks were made as early as 1948, it was not until 1967 that the position was established. ${ }^{7}$ As Snell \& Vaughan note, the decision to create the position was based largely on concerns regarding the Court's heavy workload. ${ }^{8}$ However, there is no doubt that it also received impetus from the success of clerkship programs in the American courts. Evidence of both sources of inspiration can be seen in comments of Mr. Eldon Woolliams, MP for Calgary North, made in the House of Commons during a 1968 debate regarding proposed amendments to the Judges Act: ${ }^{9}$

In defence of the Supreme Court of Canada may I say that I think that its judges are overworked. The judges of that court do not receive the assistance given to judges of the supreme court of the United States, who have many lawyers behind them to help them in research. In this country our judges have no such facilities and that is why they are overworked, no doubt. I say that the answer to that problem

B. Woodward \& S. Armstrong, The Brethren: Inside the Supreme Court (New York: Simon and Schuster, 1979).

$6 \quad$ As lamented by other commentators (see e.g. C.F. Beckton \& A.W. MacKay, The Courts and the Charter (Toronto: University of Toronto Press, 1985) at 87), the history of clerking at the Supreme Court of Canada is largely undocumented. A notable exception is Michael Herman's 1975 article, based on his experience as a clerk to Laskin C.J. (1974-75): M.J. Herman, "Law Clerking at the Supreme Court of Canadan (1975) 13 Osgoode Hall L.J. 279.

lbid.

R.S.C. 1952 , c. 159. 
is not to cut down on the number of cases that come before the Supreme Court, but to enlarge the membership of that court, if it needs to be enlarged, just as we are enlarging the membership of the Superior Court of Quebec and the County Courts of Ontario. ${ }^{10}$

The scheme approved in 1968 permitted each judge to hire one assistant. As today, clerks were typically employed for one-year terms, although the Québec judges (Fauteaux, Abbott, Pigeon and later Beetz JJ.) briefly developed a practice of retaining the same individual for two years. "The program was expanded in 1983 to allow each judge two clerks, and again in 1983 to allow the present complement of three. Both increases reflected the increased workload of the Court, as well as the success of the clerkship program.

To a large extent, the functions performed by clerks have changed little in the past twenty-six years. The primary duties continue to include the preparation of leave memoranda and bench memoranda, and the provision of assistance in the drafting of reasons for judgment. ${ }^{12}$ Nevertheless, several significant developments have altered the role of the clerks over time. The first two are linked to the evolution of Court's ability to control its own docket. In 1968, when clerks were first hired, most appeals heard by the Court, whether civil or criminal, arrived "as of right". ${ }^{13}$ However, in 1975, an amendment to the Supreme Court Act $^{14}$ eliminated the as of right appeal for civil disputes involving more than $\$ 10,000$. Thereafter, as remains true today, most civil matters (and many criminal matters) came to require a grant of "leave"; the Court's jurisdiction would be invoked only if a case raised a matter of "public importance", as identified by the Court in its discretion. ${ }^{15}$ The number of applications for leave filed increased dramatically, ${ }^{16}$ and judges came to rely more heavily upon the clerks for the preparation of leave memoranda. The original system under which each judge would have his ${ }^{17}$ clerk provide an oral or written opinion on each application soon proved unworkable. $^{18}$ Of necessity, a pooling system developed, and continues to operate

House of Commons Debates (7 October 1968) at 879.

The authors gratefully acknowledge the assistance of the Chief Justice's Office in gathering information pertaining to former clerks. See also Herman, supra note 6 at 291.

The clerks' duties are examined in detail below at Section V.

For example, in 1971, 83 percent of the appeals heard by the Court arrived as of right: S.I. Bushnell, "Leave to Appeal Applications to the Supreme Court of Canada: A Matter of Public Importance" (1981) 3 Supreme Court L.R. 479 at 497. In contrast, a clear majority of appeals now arrive by leave.

R.S.C. 1970 , c. S-19.

S.C. 1974-75-76, c. 18, s. 5; now, the Supreme Court Act, R.S.C. 1985, c. S-26, s. 40.

For example, in the 1973-74 term, 172 applications for leave were filed with the Court. In the 1975-76 term, the number had risen by 80 percent to 310 : Bushnell, supra note 13 at 503 . In the most recent term (1993-94), the Court received 513 applications.

Until the appointment of Wilson $\mathrm{J}$. in 1981, the bench was exclusively male.

As Herman notes, because of the relatively small number of leave applications received prior to 1975 , the judges were able to consider each application personally and were not required to rely significantly upon the clerks' services. Moreover, prior to the amendment of the leave process, most judges were content to receive clerks' opinions orally, rather than in written form: Herman, supra note 6 at 286. 
today, under which a memorandum prepared by one clerk is circulated to all nine judges. $^{19}$

The 1975 amendment to the Supreme Court $A c t^{20}$ had another important effect on the nature of the clerks' functions. By empowering the Court to control its own docket, the amendment fundamentally altered the nature of the appeals heard. The Supreme Court of Canada ceased to be a "court of error"; for the most part, it became able to restrict itself to cases involving issues of national importance. As appeals raising complex social issues began to appear with greater regularity, the type of research undertaken by the clerks was similarly transformed. It became increasingly necessary to consider not only the immediate impact, but also the broad policy implications, of each decision. And, of course, the enactment of the Canadian Charter of Rights \& Freedoms ${ }^{21}$ in 1982 and the clear establishment of the Supreme Court of Canada as the final arbiter of constitutional rights added yet another dimension to the judicial enterprise. ${ }^{22}$

A final significant factor in the evolution of the clerkship program stems from technological advancements. The first clerks at the Court wrote memoranda by hand or employed the services of a typist. Research consisted largely of searching through card catalogues and case report indices. Such physical constraints inevitably restricted the length of memoranda and the nature and depth of research. Today, each clerk has at his or her disposal desktop and laptop computers, electronic databases and information retrieval systems, fax machines, and other advantages of modern science. Consequently, it has become possible for clerks to prepare memoranda which are lengthier and more thoroughly researched than previously was the case. ${ }^{23}$

The introduction and expansion of the clerkship program at the Supreme Court of Canada has contributed significantly to this institution's "coming of age". Like the 1975 amendment to the Supreme Court Act, ${ }^{24}$ the use of clerks represents a move away from a conception of the judicial function as one of simply resolving a dispute between parties. By increasing the Court's capacity, and by providing perspectives not represented by litigants, clerks contribute to the larger, policy-making role assumed by the Court in recent years. ${ }^{25}$ In an article written in 1966, Brian Crane predicted that

The current system of leave memoranda preparation is considered below at Section V.

Supra note 14.

Supra note 3.

For a discussion of the impact of the 1975 amendment and the enactment of the Charter on the Court's workload, see P.H. Russell, The Judiciary in Canada: The Third Branch of the Government (Toronto: McGraw-Hill Ryerson Ltd., 1987) at 344-64.

In 1975, bench memoranda typically ran from between two and twenty pages: Herman, supra note 6 at 281 . As discussed below at Section V, the norm has changed considerably over time. Supra note 14.

The Court's evolution from a "court of error" into a policy-making institution is well documented: see for example Bushnell, supra note 13 at 486-90; Snell \& Vaughan, supra note 2 at 233-53; Laskin C.J., "The Role and Functions of Final Appellate Courts: The Supreme Court of Canada" (1975) 53 Can. Bar Rev. 469.

Professor Russell characterises the significance of clerks in the Court's evolution in the following terms: Russell, supra note 22 at 297): 
the appointment of clerks would permit Canadian judges "to cope effectively with their workload while retaining the opportunity to exercise their creative powers to the full."26 This statement has certainly proven true to a very large degree. Since their introduction nearly three decades ago, clerks undeniably have become an entrenched and indispensable part of the judicial process at the Supreme Court of Canada.

\section{THE CLERK SELECTION PROCESS}

The process by which individuals are selected to clerk at the Supreme Court of Canada is not widely known. This section will describe the steps taken by both applicants and judges during that process, and will suggest in very general terms the basis upon which candidates are chosen.

Because clerks are selected twelve to twenty months in advance of their first day of service, ${ }^{27}$ most applications received by the Court are submitted by students enrolled in their penultimate year of law school. However, there is no rule to that effect. Consequently, it is not uncommon for a student to apply during his or her final year of law school with a view to travelling, articling, pursuing graduate studies, or clerking with another court between the time of graduation and the commencement of a clerkship at the Supreme Court. Indeed, in recent years, a few individuals have been hired several years after receiving a bachelor of laws degree.

The formal application requirements are not onerous. Because an application is submitted to the Court, rather than to an individual judge, only one set of materials need be prepared. It includes a covering letter, official transcripts of all university studies and four letters of reference, one of which must be written by the Dean of the applicant's law school. ${ }^{28}$ Almost invariably, the Dean will collect the materials from all students wishing consideration and forward the bundle to the Office of the Chief Justice. ${ }^{29}$ The selection process is simplified if the Dean encloses a letter explaining the marking system used within his or her faculty. Similarly, the judges are able to more easily assess candidates if the Dean provides a rough ranking of the applicants from his or her school.

The law clerk is yet another essentially American innovation in the administration of justice in Canada and one that tends to modify the adversary system of decision-making by bringing to the judge's attention arguments or material not submitted or examined by the parties. B.A. Crane, "Law Clerks for Canadian Judges" (1966) 9 Can. Bar J. 373 at 375.

For example, all clerks hired for the 1993-94 term were selected in April/May of 1992. Most commenced their period of clerkship in early September 1993. However, because of the need to avoid a complete turnover of personnel, some clerks began at the Court as early as May, 1993, while others did not arrive in Ottawa until January of 1994.

Typically, most, if not all, of the remaining letters are written by professors well-acquainted with a candidate's skills in legal research and writing. However, testimonials may also be received by individuals otherwise able to speak to a candidate's professional or personal qualities. In that respect, as is discussed below, academic excellence is but one criteria applied by the judges.

While it is not impossible for an individual to send an application directly to the Chief Justice's Office, the submitted materials must contain a letter of reference from the Dean of Law. 
The closing date for applications varies from year to year, but inevitably occurs in late January or early February. Once it has passed, the Chief Justice's Office collects, catalogues and photocopies each application for distribution to the judges. As with other aspects of the selection process, the task has become daunting. Although complete statistics are not available, it is clear that the number of applications received annually is on the rise. For instance, in a single year between 1993 and 1994, the number of applications increased by 32 percent from 160 to 211 . This trend will likely continue as more candidates become better informed of the opportunity to clerk at the Court and as the marketplace for young lawyers both diversifies and becomes more competitive.

Given that each application is considered by all nine judges and given the already pressing workload borne by the members of the Court, a system has necessarily evolved whereby each judge relies upon his or her clerks to conduct a preliminary review of the materials received and to suggest a tentative short-list of candidates. Once that task is completed, a judge will personally select a small number of applicants and request that the Chief Justice's Office arrange interviews. ${ }^{30}$ Because interviews roughly coincide with the period of final examinations in most law schools and because of the costs inherent in cross-country travel, every effort is made to ensure that candidates chosen by several judges need visit the Court only once." And, in fact, if short-listed by one judge, a candidate is apt to be short-listed by others as well. For example, in 1994, only 80 of the 211 applicants were granted interviews, but the total number of interviews conducted was $234 .^{32}$ However, these figures can easily mislead; an individual granted a single interview may be hired, whereas an individual short-listed by many judges may not be selected. This is true because the success of any particular application depends upon a coincidence of a candidate's qualifications and a judge's needs, and upon the prevalence of certain skills within a given year's talent pool. A strong candidate who fails in his or her initial application therefore may be encouraged to re-apply.

Once interviews are completed, the final selection procedure begins. By right of position, the Chief Justice is entitled to hire three clerks immediately. Among the puisne judges, the remaining process very much resembles a draft in a sports league. Each judge is permitted to select one candidate at a time, in descending order of seniority with the Court. Thus, once the most junior judge has announced his or her first pick, the most senior judge is permitted a second selection, and so on until all positions have been filled. ${ }^{33}$

If selected for an interview, a candidate from outside the Ottawa area will receive travelling, accommodation and meal expenses. Indeed, regardless of the final outcome of the selection process, an interview is a rewarding experience in many respects. Most significantly, it provides an opportunity to meet personally with a member of the Supreme Court of Canada and thereby gain a better appreciation of one of the country's most important institutions. Exceptionally, it may be possible for candidates residing overseas to be interviewed by telephone, rather than in person. received interviews with three judges.

Because a person occasionally finds it necessary to withdraw his or her application at the last moment, successful candidates are contacted immediately upon being chosen in order to preserve the integrity of the seniority-based selection system. Were it otherwise, a junior judge would, in effect, choose out of order if a senior judge's prior selection declined a position when offered. 
It is very difficult to speak in the abstract of the basis upon which the judges exercise their selections. The process involves an art, rather than a science, and certainly there are no mechanical means by which successful candidates can be distinguished from unsuccessful candidates before the draft actually occurs. Nevertheless, some indication of the qualities commonly sought by the Court can be gathered by examining a profile of recent clerks. In that respect, Section IV of this article suggests that an applicant may be more apt to be selected if, for example, he or she has attended one of a small number of law schools, is bilingual, has received training in both the common law and the civil law, or has a history of publications which evinces an aptitude for legal research and writing. However, because the judges look not only to formal qualifications, but also to personal traits, academic excellence alone may not be sufficient to secure a position. Indeed, a judge may rely heavily upon reference letters and an interview in determining whether or not an individual is truly the most desirable candidate available. Given the tremendous workload of the Court, many clerks find their job to be trying at times. Consequently, one of the most important traits that a person can possess is an ability to perform under pressure effectively and in good humour.

\section{A BIOGRAPHICAL SKETCH OF RECENT CLERKS}

Having examined the selection process, it seems logical at this point to describe the people who have been chosen to clerk in recent years. Material is drawn from two sources. First, the Chief Justice's Office kindly provided a list of the individuals hired to serve between 1967 and 1995. Second, a questionnaire was sent to clerks who began their terms of employment between 1991 and $1993 .{ }^{34}$ Unfortunately, it was not possible to obtain complete information from even that relatively small group. Because former clerks have moved on to a variety of positions around the world, ${ }^{35}$ and because of the factors that depress the response rate in most surveys, reliable data was collected from 47 of a possible 80 individuals. $^{36}$

The survey posed the following questions:

1. At which institution(s) did you complete your law degree(s)?

2. Is your degree in Civil Law, Common Law or both?

3. Are you bilingual (English and French)?

4. What was your academic background prior to attending law school? What academic institutions did you attend?

5. Prior to commencing your clerkship, had you been published? If so, please provide details.

6. Did you clerk at any other court prior to commencing your clerkship?

7. Do you plan to pursue an academic career, or to practice law or both? Do you plan to remain in the legal profession?

8. In which types of extra-curricular activities were you involved during law school (e.g. moots, law review, legal aid).

The authors gratefully acknowledge the assistance of Graham Flack (clerk to Gonthier J., 1993-94) in locating many former clerks.

While 27 clerks are employed by the Court in each year under consideration, one individual served for two terms. Hence, over the three year period between 1991 and 1993, the total number of individuals who clerked was 80 , rather than 81 . 
Given the limited nature of the resources available in the preparation of this article, the ensuing discussion clearly is not comprehensive, nor is it intended to provide a profile of the "average clerk" ${ }^{37}$ Rather, its aim is to convey, in a general way, some sense of the people who have served at the Court in recent years. Individuals considering applying for a position should not be discouraged by the fact that they may not possess some of the qualifications that will be mentioned. The clerks are a varied group and the factors that lead to the selection of any particular individual depend a great deal upon the needs of a particular judge.

The first point to be noted pertains to the representation of the sexes. While clerks were initially hired in 1967, it was two more years before a woman served at the Court; in 1969, Hall J. employed Susan Steer Gibson. Moreover, notwithstanding the occasional presence of a female clerk thereafter, the position long remained maledominated. Until 1978, no more than two women served simultaneously, and as late as 1979, every clerk serving with the Court was a man. However, there is no reason to assume that there was active discrimination within the Court during the early years of the clerkship program. The lack of women at the Court undoubtedly was largely a function of the limited number of women graduating from Canadian law schools at that time.

Since the early 1980s, the number of women at the Court has increased sharply. This trend cannot be explained simply on the basis that the number of clerks permitted to each judge rose from one to three during the last decade; in recent years, the clerks have been predominantly female. Of the individuals hired to commence their period of clerkship between 1991 and 1995, 72 were women and 63 were men. ${ }^{38}$ Once again, however, it is unlikely that any judge specifically favours one sex over the other. The selection process is based on relevant credentials, not merely personal characteristics; the fact that more women than men have been hired in recent years is more plausibly explained on the basis of the applications received by the Court. ${ }^{39}$

While the questionnaire provided to former clerks did not ask of other personal characteristics, a few observations can be offered. First, while most are single, it is by no means unusual for a clerk to have a partner and/or children. Similarly, though the majority of clerks arrive at the court during their mid to late twenties, some, having entered law school relatively early in life, are younger, while others are considerably older. It would be most unfortunate if a potential candidate assumed otherwise and refrained from applying as a result.

The dangers of generalising on the basis of the limited sample are obvious. Apparent trends actually may be attributable to coincidence, and hence may be illusory. For example, the fact that a particular law school has placed $X$ number of students at the Court in the past five years does not yield the conclusion that it will enjoy the same success over the next five years.

Since the clerkship program was introduced in 1967, men have outnumbered women by approximately 251 to 130 . It is impossible to be precise because of the difficulty in determining the sex of some individuals on the basis of name alone, and because the information available for the preparation of this article listed several former clerks by surname and initials only. 
The questionnaire distributed to former clerks inquired as to their educational background, aside from law school. Of the 47 respondents, 41 held bachelor degrees. ${ }^{40}$ Of that group, 30 had graduated in arts, six in science, three in fine arts, and one each in education and commerce. Interestingly, 14 of the respondents entered law school with a masters degree, and one individual held a doctorate prior to commencing legal studies. ${ }^{41}$ Because it is far more common for clerks to undertake graduate studies in law after completing a period of clerkship, only one respondent held an LL.M. and a Ph.D. in law before serving at the Court. The precise extent to which the judges are influenced by such factors during the selection process is impossible to determine. Nevertheless, an applicant surely benefits in some measure from any special qualification which he or she has received, particularly if it evinces an ability to research, analyse and write effectively.

Information with respect to legal training was available for 111 clerks hired to serve between 1991 and $1995 .^{42}$ Members of that group represent seventeen of Canada's twenty-one law schools. However, as might be expected, the numbers are not equally distributed; some schools placed several clerks at the Court every year, while others only occasionally enjoyed that honour. The University of Toronto and McGill University easily topped the list with 22 and 17 clerks respectively. The figures for the remaining schools are as follows: the University of Ottawa (10 students), the University of British Columbia (9), Dalhousie University, Osgoode Hall Law School and the University of Alberta (8 each), Queen's University and the Université de Montréal (5 each), Universite Laval (4), the University of Windsor, the University of Western Ontario and the University of Victoria ( 3 each), the University of Manitoba and the University of New Brunswick (2 each), and the University of Saskatchewan and the University of Calgary (1 each). ${ }^{43}$

The uneven representation of law schools may be explained by a number of factors. First, some law schools are larger than others; all else being equal, a graduating class of less than 80 cannot be expected to produce as many clerks as a graduating class of more than 300 . Second, certain universities enjoy particularly favourable reputations

Six respondents did not hold a bachelor's degree prior to beginning their legal education. Some proceeded directly to law school from CÉGEP in Quebec, while others were admitted to law school on the basis of partial satisfaction of degree requirements in various disciplines. In addition, many of the clerks had earned various other certificates and qualifications prior to entering law school.

Because most clerks are hired directly out of law school, legal training outside the classroom does not appear to be a particularly important consideration in the selection process. Very few of the individuals who responded to the survey indicated that they had articled or had been admitted to the bar prior to commencing their clerkship. Moreover, while most clerks at the United States Supreme Court clerk elsewhere before moving to Washington (D.M. O'Brien, Storm Center: The Supreme Court in American Politics, 2d ed. (New York: W.W. Norton \& Co., 1991) at 160-61), it is unusual for an individual to arrive at the Supreme Court of Canada having previously clerked at another court.

43 In terms of regional representation, 49 clerks graduated from Ontario law schools, 26 from law schools in Quebec, 12 from prairie province law schools, 12 from law schools in British Columbia, and 10 from law schools in the maritime provinces. 
which benefit their graduates. ${ }^{44}$ Third, some law schools provide their students with special skills which may prove advantageous in the selection process. For example, the judges often respond to the fact that McGill University and the University of Ottawa offer training in both official languages and in both of Canada's legal systems. Fourth, for a variety of reasons, a judge may tend to hire clerks who graduated from universities in his or her home province or region; ${ }^{45}$ however, this factor is easily overstated, as the selection process involves many considerations of which geography is but one. Finally, it appears that the presence of former clerks within a law school is correlated to the successful application rate of its students. ${ }^{46}$ While many factors are undoubtedly involved, it seems more than mere coincidence that, for example, the University of Toronto and McGill University each have many former clerks on staff and each place several clerks with the Court each year. ${ }^{47}$

As suggested in the preceding paragraph, while certainly not necessary, bilingualism is unquestionably an asset for prospective clerks. Ideally, a clerk is able to assist his or her judge with the materials written in both French and English. ${ }^{48}$ Consequently, it was not surprising to find that of the 47 individuals who responded to the questionnaire, 24 were fluently bilingual, while another 9 were functionally proficient in both official languages. An applicant is similarly advantaged if he or she has received training in both of Canada's legal systems. However, the incidence of bijuridical clerks is far less pronounced than the incidence of bilingual clerks. Of the individuals who responded to the questionnaire, only 9 held degrees in both common law and civil law. Thirty four were trained exclusively in the former, and 4 were trained exclusively in the latter. ${ }^{49}$

Judges undoubtedly are interested in knowing whether or not a candidate has a proven ability to write clearly. Most individuals are hired while in their second or third year of law school, and therefore have had little opportunity to publish prior to applying

4 Certainly, outstanding clerks have graduated from law schools across the country. Nevertheless, it seems safe to assume, for example, that one reason for the tremendous success of the University of Toronto in placing graduates at the Supreme Court of Canada lies in the high reputation enjoyed by its law school.

4s To the limited extent that it does occur, geographical hiring has the salutary effect of ensuring regional diversity among the clerks.

46 It can be speculated that the presence of former law clerks may contribute to a culture which promotes successful applications to the Supreme Court. For example, students may receive information, encouragement and particularly helpful reference letters from professors who previously clerked.

47 It is difficult to determine whether or not geography plays a role in application rates. Conceivably, students from some law schools may be discouraged by the fact that their provincial law society does not recognise a year at the Supreme Court of Canada as complete satisfaction of the articling requirement. Similarly, some students may be unwilling to move great distances to be in Ottawa for one year. However, the list of individuals who applied to serve during the 1995-96 term casts some doubt on those suggestions; large numbers of candidates applied from across the country. In that regard, it should be noted that cases argued in French do not invariably originate in Quebec.

49 The figures are consistent with the judges' needs. For example, in 1993, 11 percent of the appeals heard by the Court originated in Quebec; most of those cases, however, concerned matters governed by laws also applicable in common law jurisdictions. Thus, the Quebec Civil Code presented the primary issue on appeal only 2 percent of the time. 
to the Court. Nevertheless, perhaps because it is often perceived as an important stepping stone to a career in academia, the position does attract a significant number of applicants with literary inclinations. Thus, while few of the 47 questionnaire respondents had published legal articles prior to being hired, ${ }^{50} 15$ had produced work which was accepted by, or actually appeared in, law journals by the time their clerkship began. Furthermore, approximately one third of the respondents had served on a law review editorial board during law school.

Given the desirability of hiring interesting, well-rounded individuals, judges also consider other types of extra-curricular activities undertaken during studies. It is therefore not surprising to find that over half of the questionnaire respondents had been involved in moot court competitions. Several others mentioned involvement in legal aid services, faculty research projects, feminist organisations and student organised "skit nights".

Finally, the questionnaire inquired as to the clerks' future plans. Because of the broad range of answers received, it is impossible to discuss the survey results in concrete terms. On a general level, however, it can be noted that a strong majority intended to practice in the foreseeable future. Some members of that same group also expressed an interest in simultaneously teaching law, and approximately one-fifth of the respondents indicated that their primary or exclusive interest was in the academic world. And, finally, a small number of individuals were uncertain as to whether they wished to remain in the legal profession at all.

The responses are not unexpected. First, it is no longer true (if it ever was true) that a clerkship at the Court is a guarantee of success. Today, the marketplace is such that recent graduates frequently find it difficult to secure preferred positions in private practice, the public sector or academia notwithstanding superior qualifications, such as periods of clerkship with courts, graduate degrees in law or outstanding law school grades. Nevertheless, a clerkship with the Supreme Court of Canada undoubtedly is a valuable asset which occasionally opens doors that would otherwise remain shut. On a more positive note, the uncertainty which many of the respondents expressed is attributable not only to prevailing economic conditions, but also to the unprecedented range of choices now open to law school graduates. While many clerks will follow traditional paths in law firms and law schools, others will exploit their training in new and imaginative ways.

Accordingly, it can be expected that at least some recent clerks will follow in the footsteps of their predecessors and achieve positions of prominence in Canadian society, whether it be in academia, ${ }^{51}$ private practice, ${ }^{52}$ the judiciary, ${ }^{53}$ or some other sector. prior to being hired.

31 Many former clerks have gone on to outstanding careers in academia. An incomplete list includes Wade MacLauchlan (Estey J., 1981-82), Joseph Magnet (Dickson J., 1976-77), John McCamus (Laskin C.J., 1970-71), Stephen Perry (Wilson J., 1983-84), and Katherine Swinton (Dickson J., 1975-76). 


\section{THE FUNCTIONS OF A LAW CLERK}

The number and nature of the clerks' tasks vary, sometimes significantly, with the needs and expectations of the various judges. For example, if a judge wishes to deliver a speech, it may fall upon a clerk to assist in the drafting of the lecture; if a judge has prepared an article for publication, a clerk may be asked to proofread the paper or check footnote citations. More substantively, one judge generally may demand that each issue raised in an appeal be the subject of extensive research prior to hearing, while another may direct that research be focussed on specified matters. So, too, the extent to which a judge relies upon a clerk's services may be a function of the amount of confidence that the clerk has inspired on the basis of past performance. Nevertheless, there are basic services which are performed by all twenty-seven clerks: (a) the preparation of leave memoranda, (b) the preparation of bench memoranda, and (c) the provision of assistance in the drafting of reasons for judgment. Each will be examined in turn.

\section{A. LEAVE MEMORANDA}

While there are various ways in which a matter may come before the Supreme Court of Canada ${ }^{54}$ the most common is through a grant of leave. For example, of the 133 appeals heard in 1993, nearly 80 originated with leave applications. ${ }^{55}$ However, it must not be thought that the leave process is an easy means of access; while many call, few are chosen. The Court receives in the neighbourhood of 500 applications each year, ${ }^{56}$ but exercises its discretion in favour of allowing a hearing only about 20 percent of the time.

Clearly, given the number of applications filed, it would be inefficient and impractical, if not impossible, for every member of the Court to assume an active role in the determination of each file. Accordingly, most applications are determined by one

Among the many clerks who have become outstanding practitioners are Neil Finklestein (Laskin C.J., 1980-81), David Matas (Cartwright C.J., 1968-69) and Douglas Stollery (Martland J., 197677).

33 Among the former clerks who now serve in the judiciary are Louise Arbour J.A. of the Ontario Court of Appeal (Pigeon J., 1971-72), Jean Côté J.A. of the Alberta Court of Appeal (Martland J., 1967-68), Nola Garton of the Ontario Court, General Division (Judson J., 1973-74) and Daniele Tremblay-Lamer J. of the Federal Court, Trial Division (Lamer J., 1982-83). No member of the Supreme Court of Canada ever previously served the Court as a clerk. In contrast, in the United States, three former Supreme Court clerks have been appointed to that bench: William Rehnquist C.J. (clerk to Jackson J.), John Paul Stevens J. (clerk to Rutledge J.), and Byron White J. (clerk to Vinson C.J.).

For a useful summary of the various means by which a case or reference may appear before the Court, as well as the history of the leave requirement, see B.A. Crane \& H.S. Brown, Supreme Court of Canada Practice, 1994 (Toronto: Carswell, 1993) at 1-30. Of the remaining matters, most came before the Court pursuant to the as of right provisions in the Criminal Code.

so In 1993, the Court received 513 applications for leave, and increase of 11.5 percent over the previous year's total of 460 . 
of three leave panels, ${ }^{57}$ each of which is comprised of three judges. ${ }^{58}$ The panel to which an application is assigned takes into account the views of other members of the Court, but ultimately makes the final decision alone.

To further maximise the use of the Court's resources, the clerks pre-screen the applications and provide recommendations as to dispositions. ${ }^{59}$ Each clerk is associated with one of the three leave panels.$^{60}$ Approximately once a week, a list is distributed indicating the applications which have been assigned to each panel. At that point, responsibility for distribution falls to the clerks; one clerk associated with the panel to which an application has been assigned will volunteer to prepare a "leave memo". The process is honour-based; while formal enforcement mechanisms do not exist, each clerk knows that he or she is expected to complete approximately 20 memos per year. ${ }^{61}$ Where basic notions of fairness fail to take hold, peer pressure generally prevails; exceptional circumstances aside, the system operates smoothly and each clerk shoulders an equitable share of the work.

Depending on the nature of an application and a clerk's style of research and writing, a leave memo may range in length from 4 to 40 pages, but typically is in the

At the time that this article was written, the three panels were comprised of (1) Lamer C.J., Cory and lacobucci JJ., (2) L'Heureux-Dubé, Gonthier and McLachlin JJ., and (3) LaForest, Sopinka and Major JJ. However, the composition of the panels is fluid, and may be altered from time to time. Furthermore, an application exceptionally may be assigned to more than three judges, and may even be considered by the entire Court.

While a leave application may involve an oral hearing, the vast majority are determined on the basis of written materials alone.

s9 Shortly before this article went to print, the system used for the determination of leave applications was altered slightly. As in the past, once received by the Court, an application is first sent to the Legal Affairs Department of the Supreme Court where a staff lawyer prepares an objective summary of the facts, issues and arguments involved. However, in clear cases, the lawyer will now also provide a tentative recommendation as to the disposition of the application. Depending upon which panel is assigned to the application, the file may then be sent immediately to a clerk for confirmation or rejection of the recommendation. Alternatively, a panel may request a clerk's services if it wishes to have further analysis conducted.

The full implications of the new system are not yet known. In time, the role of staff lawyers may expand further and the present system of pooling among the clerks may disappear altogether. Of course, the procedure ultimately adopted will be that which best serves the interests of justice.

The authors wish to thank Mr. Justice Major and Randal Van de Mosselaer (clerk to Major J., 1993-94) for providing the preceding information.

Typically, a clerk is associated with the same panel as his or her judge, but for linguistic or other reasons, variation is sometimes necessary.

6) Individuals contemplating applying for a position with the Court may wish to consider the nature of the work performed by the clerks. In 1993, the 513 leave applications were received in the following areas: criminal law (24 percent), procedural law (12 percent), the Charter (11 percent), torts $(8$ percent), administrative law ( 8 percent), property law ( 5 percent), taxation ( 4 percent), the Quebec Civil code (2 percent), constitutional law (2 percent), and others (12 percent). The figures cited refer to the primary issue raised in an application. Of course, for example, an application principally concerned with criminal law may also raise issues regarding the Charter. 
order of 15 pages long. ${ }^{62}$ Invariably, it states the essential facts, provides a procedural history of the case, summarises the decisions of the lower courts, and states the issues. Depending upon a clerk's inclinations and the expectations of his or her judge, an additional section may summarise the parties' submissions. The most important, and typically longest, part of the memo examines whether or not the application should be granted. In that regard, guidance normally is taken from s. 40(1) of the Supreme Court $A c t$, which provides that the Court may grant leave to appeal if it is of the opinion that an application raises a question which:

[B]y reason of its public importance or the importance of any issue of law or any issue of mixed law and fact involved in that question, is one that ought to be decided by the Supreme Court of Canada or is, for any other reason, of such a nature or significance as to warrant decision by it.... ${ }^{63}$

In the context of leave memos, a clerk's research is aimed at answering a number of questions. Are the issues raised of public importance, or are they significant to the litigants alone? Are they the subject of uncertainty? Have they been decided differently by different appellate courts? Has the Supreme Court of Canada recently spoken to the primary questions posed in the application? If so, it may be desirable to allow the lower courts time to settle subsidiary matters before speaking again. Has leave been granted in another appeal which raises the same, or similar, issues and for which judgment is still pending? If so, it may be unnecessary to grant leave. However, if the other appeal has yet to be heard, it may be desirable to hear both matters together.

Conspicuously absent from the preceding list of questions is one that asks whether or not a case was correctly decided in the court below. Often, whether through a misunderstanding of the Court's jurisdiction or simply through wishful thinking, lawyers wrongly approach the Supreme Court of Canada as though it is a court of error which exists to rectify all mistakes committed by lower courts. Consequently, many applications are filed which clearly do not satisfy the leave requirements set out in the

An interesting contrast can be made with the practice in the United States Supreme Court. Consistent with the relative populations of the two countries, the American Court receives approximately 10 times the number of applications for leave (or "petitions for certiorari") as the Canadian Court. Because there are only slightly more clerks at the U.S. Supreme Court, a different system of processing necessarily is used south of the border. As in Canada, all members of the Court generally rely upon the same memo. However, whereas a leave memo prepared in the Supreme Court of Canada typically runs to 15 pages, "cert. memos" prepared in the United States Supreme Court are typically limited to a page or two. On the other hand, in the United States, each memo is reviewed by a clerk in every chambers. Only one member of the Supreme Court of Canada presently requires his clerks to comment on leave memos prepared by clerks working for other judges.

For a discussion of the functions of law clerks in the United States Supreme Court, see O'Brien, supra note 42 at 156-70; B. Schwart, A History of the Supreme Court New York: Oxford University Press, 1993) at 369-72; W.H. Rehnquist, The Supreme Court: How It Was, How It is (New York: Morrow \& Co., 1987) at 263, 272-73, 297-301 [hereinafter How It Was]; W.H. Rehnquist, "Who Writes Decisions of the Supreme Court?" (1957) XLIII:24 U.S. News \& World Report 74 [hereinafter "Who Writes Decisions"]; K. Hall, The Oxford Companion to the Supreme Court of the United States (New York: Oxford University Press, 1992) at 159-61. 
Supreme Court $A c t^{64}$ and other statutes. True, when preparing a leave memo, a clerk will typically offer a summary assessment of the lower court's judgment. However, a negative appraisal alone is not sufficient to warrant a positive recommendation; at most, it may buttress the arguments in favour of granting leave in a borderline application.

It is difficult to gauge the clerks' impact upon the leave determination process. ${ }^{65}$ Although statistics are not publicly available for the Supreme Court of Canada, it is known, for instance, that Vinson C.J. of the United States Supreme Court rarely deviated from his clerks' recommendations. ${ }^{66}$ However, that statement is misleading. First, because the proper disposition of most applications is uncontentious, the clerks' efforts typically are a matter of convenience rather than influence. Second, while perhaps pronounced in the United States, the danger of clerks exercising undue influence is minimal in Canada. As noted above, ${ }^{67}$ different systems are used for processing leave applications in the two countries; a judge is much less likely to be misled by a fifteen page memo than by a one page memo.

\section{B. BENCH MEMORANDA}

In recent years, the Supreme Court of Canada has heard, on average, between 125 and 135 appeals annually. The burden on each judge is considerable, ${ }^{68}$ and without assistance, the members of the bench would undoubtedly find it difficult to fully prepare for each hearing. Accordingly, the Justices have come to rely upon the clerks for the preparation of pre-hearing memoranda ${ }^{69}$ Typically, each judge assigned to a case asks one of his or her clerks to prepare a "bench memo". ${ }^{70}$ However, variations do occur. Some judges request their clerks to prepare memos on selected cases only. And occasionally, if the pressures bearing upon a clerk become too great, that person may, with his or her judge's permission, borrow a bench memo prepared by a colleague for another judge.

Ibid.

In the United States, fears have been expressed that clerks exercise undue influence on the disposition of petitions for certiorari: see e.g. Schwart, supra note 62 at 370-71; "Who Writes Decisions", supra note 62 at 75; P.B. Kurland, "Book Review of The Supreme Court: How It Was, How It Is, by W.H Rehnquist" N.Y. Times (20 September 1987) Section 7, 3 at 40 . The issue of the clerks' influence is more fully explored below at text accompanying notes 68-79.

In the years 1947-52, Vinson C.J. agreed with his clerks' recommendations between 95.9 and 97.2 percent of the time: O'Brien, supra note 42 at 168.

Supra note 62.

For example, during the 1993-94 term, each judge heard, on average, 81 appeals. Moreover, in many instances, a single appeal involved several cases.

Justices of the United States Supreme Court also rely on their clerks for the preparation of "bench memos". The Canadian documents and the American documents are similar in both name and content: O'Brien, supra note 42 at 166; How It Was, supra note 62 at 272-73.

Individuals contemplating applying for a position with the Court may wish to consider the nature of the work that they will be expected to perform. In 1993, the 133 appeals were heard in the following areas: criminal law ( 41 percent), the Charter ( 33 percent), torts ( 8 percent), taxation (3 percent), constitutional law ( 3 percent), labour law ( 3 percent), administrative law ( 3 percent), and others (7 percent). The figures cited refer to the primary issue raised in an appeal. Of course, for example, an appeal principally concerned with criminal law may also raise issues regarding the Charter. 
Bench memos and leave memos share many features. For example, both generally contain a recitation of the facts and procedural history of the case in question, as well as a summary of the lower courts' decisions and perhaps the parties' arguments. However, there are important differences. Most obviously, bench memos are typically much longer than leave memos. On average, the former run to between 20 and 45 pages, as compared with 15 for the latter. Once again, however, length can vary significantly depending upon the number and complexity of issues raised, the number of parties submitting factums, the instructions and expectations of a particular judge, and the writing and research style of a particular clerk. An especially complicated matter may demand a bench memo in the order of 75 pages, but in a simple appeal, a judge's needs may be met in less than 15 .

A bench memo also differs from a leave memo with regard to purpose, and hence content. Whereas the latter assists the Court in determining the relatively simple question of whether or not an appeal should be heard, the former assists a judge in determining the more difficult question of how an appeal should be decided. Accordingly, a good bench memo, like a good law school examination answer, thoroughly considers each pertinent issue with a view to discovering how the relevant rule of law ought to be formulated and applied. The exercise is, of course, based on analysis rather than advocacy. While a clerk typically arrives at a recommendation, generally speaking, it is not the proper function of a clerk to champion one side or another in an appeal. Rather, a clerk should provide his or her judge with a critical examination of the parties' arguments and a thorough exegesis of the applicable law."

In many cases, particularly if he or she seeks the judge's guidance before drafting, a clerk's role in the pre-hearing phase of an appeal ends upon completion of a bench memo. However, having received a memo, a Justice may contact the responsible clerk to request that additional research be conducted, or simply to discuss a contentious issue. A bench memo may not adequately have explored an important issue, or it may have raised a novel point or perspective which intrigues the judge.

As might be expected, bench memos typically consume a considerable portion of a clerk's energy. Although circumstances vary significantly, it would not be unusual for time to be allocated along the following lines: bench memos: 50 percent; leave memos: 25 percent; judgments: 15 percent; miscellaneous: 10 percent. However, while those figures may remain constant, any particular task is apt to require less time at the end of the year than at the beginning of the year. Most clerks begin their term at the Court with little previous legal experience outside of the classroom. Consequently, for example, the preparation of a first bench memo may stretch on inefficiently. Of necessity, clerks quickly recognise the basics of time management and acquire the skills needed to work effectively. Moreover, they come to share the judges' appreciation of occasionally find it difficult to set aside personal beliefs and to provide entirely objective analyses. And, in fact, in the context of a particular case, a judge may welcome a clearly identified alternative perspective as a means of better appreciating the implications of an appeal. However, for the most part, clerks should strive for neutrality. 
the practicalities of the judicial process; it is impossible to examine exhaustively every issue raised in every case. Given the nature of the appeals that come before the Court, many bench memos, like many judgments, could expand to fill volumes if time permitted. Few members of the legal community mourn the fact that reality dictates otherwise.

\section{JUDGMENT WRITING}

At the conclusion of the parties' arguments, the members of the Court comprising the coram will meet in conference ${ }^{72}$ and one or more judges will be assigned the responsibility of delivering reasons for judgment. ${ }^{73}$ Often, though not always, the clerks again are involved. ${ }^{74}$

A clerk's role depends entirely upon his or her judge's approach to writing. Occasionally, at least, a judge may personally undertake the process of drafting reasons from start to finish, and employ a clerk, if at all, for proofreading services. Generally, however, greater reliance is placed on the clerks. Typically, having heard argument, a judge meets with the clerk who wrote the bench memo for the appeal under consideration, describes in fairly specific terms the reasoning to be employed and the result to be reached, and requests that a draft judgment be prepared. Once the clerk completes the initial task, the judge invariably asks that alterations be made. ${ }^{75}$. Exceptionally, if a clerk began with a very clear understanding of both the case on appeal and his or her judge's expectations, the changes may be relatively minor or simply of a stylistic nature. More commonly, the written reasons must be substantially clarified or tightened. And not infrequently, as in any writing exercise, a first draft may simply focus the analysis and eventually serve as a mere blueprint for the final product. In any event, the editing process is usually repeated several times before the judge is satisfied.

Once completed, a draft opinion is circulated for consideration by the other members of the Court who heard the appeal. And again, the clerks' services may be employed.

The process described in the text pertains to appeals in which reasons are reserved. In recent years, the Court has rendered judgment from the bench in approximately one-third of the cases it has heard. In such situations, which typically arise in the context of of right criminal appeals, the conference is abbreviated and the clerks typically have no role to play in the judgment process. Conferences are conducted privately and are closed to the clerks.

14 That the judges do rely upon the clerks should come as no surprise to anyone familiar with the judicial process. An observation by Rehnquist C.J. of the United States Supreme Court would appear to be equally applicable in this country:

I don't think people are shocked any longer to hear that an appellate judge receives a draft of a proposed opinion from a law clerk.... I think they would be shocked, and properly shocked to learn that an appellate judge simply "signed off" on such a draft without fully understanding its import and in all probability making some changes in it. The line between having law clerks help with one's work, and supervising subordinates in the performance of their work, may be a hazy one, but it is at the heart ... [of] the fundamental concept of "judging".

Quoted in O'Brien, supra note 42 at 167. 
Frequently, a judge will ask the clerk who prepared the bench memo for the case in question to comment upon the circulating judgment with a view to determining whether or not it should be joined, with or without alterations. Depending upon the judge's degree of bilingualism, one of his or her clerks may also be asked to provide a translation of the draft opinion. For that reason, among others, each chamber should contain at least one bilingual clerk.

One occasionally encounters the suggestion that Supreme Court clerks wield too much power; in particular, it is sometimes alleged that clerks do not merely assist in the drafting of opinions, but actually write judgments. ${ }^{76}$ Though not as prevalent in this country, the criticism is often heard in the United States. For example, Professor Kurland has recalled the manner in which past Justices operated, noted the extent to which the American Court now relies upon its clerks, and suggested that "Brandeis would be aghast." ${ }^{\text {"7 }}$ Similarly, Professor Mann has disparagingly written that clerks in the United States Supreme Court "frequently write judgments which their masters often merely adopt and which a qualified observer can easily recognise as the work of a beginner." ${ }^{78}$

Interestingly, four years after serving as a clerk to Jackson J. and many years before becoming a Justice of the United States Supreme Court himself, William Rehnquist spoke of the undue and subversive influence which clerks often had on the decision making process. ${ }^{79}$ While Chief Justice Rehnquist now defends the role assigned to clerks, in 1957, he offered the following observations.

Most of the clerks are recent honor graduates of law schools, and, as might be expected, are an intellectually high-spirited group. Some of them are imbued with deeply held notions about right and wrong in various fields of the law, and some in their youthful exuberance permit their notions to engender a cynical disrespect for the capabilities of anyone, including Justices, who may disagree with them.

The bias of the clerks, in my opinion, is not a random or hit-and-miss bias. From my observations of two sets of Court clerks during the 1951 and 1952 terms, the political and legal prejudices of the clerks were by no means representative of the country as a whole nor of the Court which they served.

Recently, Mahoney J.A. considered in dicta the question of whether or not "consultation by a decision maker before publishing a decision, including consultation by a judge with a law clerk" could be abused so as to entail a reasonable apprehension of bias. The answer, it was suggested, lies in "whether an informed person, viewing the matter realistically and practically and having thought it through, would think it more likely than not" that a decision was influenced by a clerk: Weerasinge v. Canada, [1994] 1 F.C. 330 at 338 (F.C.A.).

$\pi \quad$ Kurland, supra note 65.

7 F.A. Mann, "Brief for a Separate Bar" The Times (London) (11 July 1986) 16.

79 Rehnquist C.J. is not the only member of the American Court to have expressed concern regarding the role of clerks. Over the years, some members of the bench have refused to participate in the "cert. pool" system under which several judges share a leave application memorandum drafted by one clerk. And Douglas J. once observed that, "The law clerks are fine. Most of them are sharp and able. But after all, they have never been confirmed by the Senate": Schwartz, supra note 62 at 371 . 
After conceding a wide diversity of opinion among the clerks themselves, and further conceding the difficulties and possible inaccuracies inherent in the political cataloguing of people, it is nonetheless fair to say that the political cast of the clerks as a group was to the "left" of either the nation or the Court.

Some of the tenets of the "liberal" point of view which commanded the sympathy of a majority of the clerks I knew were: extreme solicitude for the claims of Communists and other criminal defendants, expansion of federal power at the expense of State power, great sympathy toward any government regulation of business - in short, the political philosophy now espoused by the Court under Chief Justice Earl Warren.

There is the possibility of the bias of the clerks affecting certiorari [i.e. leave application] work.... I cannot speak for any clerk other than myself in stating as a fact that unconscious bias did creep into his work. Looking back, I must admit that I was not guiltess on this score, and I doubt if any of my fellow clerks were much less guiltless than I. And where such bias did have any effect, because of the political outlook of the group of clerks, its direction would be to the political "left". 80

Finally, some American commentators have invoked literary considerations in decrying the United States Supreme Court's employment of recent law school graduates.

For three years they have drummed into them that the acme of literary style is the law review article. It is scarcely surprising that the standard opinion style has become that of student-run reviews: colorless, prolix, platitudinous, always error on the side of inclusion, full of lengthy citations and footnotes - and above all dull. ${ }^{81}$

The fact that a judge will invariably review and personalise a draft opinion does little to appease nostalgic critics.

The individual flair that makes the opinions of a Holmes or a Cardozo literary as well as legal gems has become a thing of the past. There is all the difference in the world between writing one's own opinions and reviewing opinions written by someone else. It is hard to see how an editor can be a great judge. Can we really visualize a Holmes coordinating a team of law clerks and editing their drafts? ${ }^{82}$

Whatever the situation south of the border, clerks in this country do not exercise an improper degree of authority. Any suggestion that Canada's Justices abdicate their responsibilities for writing judgments is false; in every instance, a decision of the Court ultimately and fundamentally is the product of the nine men and women who sit on the bench. ${ }^{83}$ Of course, that is not to deny that the clerks enjoy some input. ${ }^{84}$ For

"Who Writes Decisions", supra note 62 at 75.

s) Schwartz, supra, note 62 at 372.

$\$ 2 \quad$ lbid.

83 In a recent speech to students at the Dalhousie Law School, Justice Major suggested, with characteristically self-deprecating wit, that the contrary view "does not flatter the clerks": Major J., Address (Dalhousie Law School Students, 20 January 1994) [unpublished]. 
example, a judge who votes tentatively at conference may revise his or her position to take account of a previously overlooked theory or authority which a clerk discovers only in the course of post-hearing research. Furthermore, because of the time constraints imposed on the judges, it would seem impossible for them, acting alone, to conduct the breadth and depth of research that currently informs their decisions. And it may be, in some instances, that judgments are lengthier as a result of the clerks' presence. ${ }^{85}$ Finally, it seems unlikely that the Court would be able to render its decisions as quickly as it presently does, but for the services of the clerks. ${ }^{86}$

Nor can it reasonably be argued that, regardless of authorship of judgments, Canadian clerks enjoy positions of great persuasion. As Alexander Bickel observed on the basis of his experience at the United States Supreme Court, clerks "are in no respect any kind of powerful kitchen cabinet." ${ }^{187}$ Because a term of employment at the Supreme Court of Canada rarely exceeds twelve months, even the most ambitious clerk would find it difficult to win from a judge the degree of confidence required for the exercise of significant influence. More importantly, there is an obvious disparity in knowledge and experience between the members of the Court and their clerks. While a clerk exceptionally may enjoy an area of some expertise, the fact remains that even the brightest person, having recently completed three or four years of law school, plus perhaps a graduate degree in law or a year's clerkship with another court, will lack both the degree of specialised learning and the broad understanding of the law that comes only with time.

frequent reliance on the Harvard Law Review is partially a function of the number of graduates of the Harvard Law School that clerk at the highest court. While unable to determine the type of resources which might be attributable to Canadian clerks, Black \& Richter thought it reasonable to conclude that "the clerks might have some effect by bringing certain sources to the judges' attention while deciding that other sources discovered in their research are not useful or relevant": V. Black \& N. Richter, "Did She Mention My Name?: Citation of Academic Authority by the Supreme Court of Canada, 1985-1990" (1994) 16 Dalhousie L.J. 377 at 386.

While it is not quite true that the annual number of Supreme Court Report volumes accurately reflects the number of clerks employed by the Court, there does appear to be some correlation between the two variables. In 1983, most judges began to hire a second clerk, and in 1989, the number of clerks rose to three per judge. The S.C.R. first appeared in two volumes in 1975. In 1989, when the Court acquired its present complement of 27 clerks, the S.C.R. again was comprised of two volumes, but one of those volumes was sufficiently large so as to be produced in two parts. Since 1989, the S.C.R. has appeared as three annual volumes.

Currently, the S.C.R. runs to in excess of 3,000 pages per year. For better or worse, it seems unlikely that the members of the Court could produce such a corpus but for the assistance of the clerks.

In recent years, the Court's ability to issue judgments in a timely manner has increased dramatically. For example, in 1989, 149 judgments were rendered. The average time lag between the date of hearing and the date of judgment was 6.51 months, and some 55 appeals remained standing for judgment at the end of the year. In 1993, approximately the same number of judgments (150) were rendered. However, the average time lag between hearing and judgment had dropped to 4.05 months, and the number of appeals still standing for judgment at the end of the year was only 32. Partial figures available for 1994 confirm that trend; as of 31 August 1994, the average delay between hearing and judgment was a mere 2.79 months.

Undoubtedly, a number of factors contributed to those improvements. However, it does seem unlikely that the Court could have reached its current state of efficiency without the assistance of the clerks. 


\section{THE CLERKING EXPERIENCE}

Because of the many variables that may affect a clerk's workload and his or her ability to efficiently manage time, it is somewhat difficult to generalise about the work experience at the Court. ${ }^{88}$ The stereotypical view of exceedingly long hours and intense pressures certainly proves true for a number of individuals each year. It is not unusual for clerks to occasionally work well into the night and to spend at least part of every weekend at the office. However, by no means is a monastic lifestyle invariably required. Many clerks are able to work reasonable hours, and often it is entirely possible to easily balance professional responsibilities with the responsibilities of a spouse, partner or parent. Indeed, some clerks also are able to accommodate timeconsuming, extracurricular interests, such as sporting activities or law review writing.

It is similarly difficult to generalise about the social experience at the Court. As between judges and clerks, personal relationships vary widely. Within the work environment, some members of the bench prefer to communicate primarily by way of memoranda or telephone, while others schedule regular meetings each week. Similarly, outside the Court, some judges prefer to divorce the professional and the personal, while others occasionally arrange to meet with their clerks for a game of squash or a day of skiing.

As might be expected, socialising is far more common amongst the clerks. Many share interests, most are from outside the Ottawa area, and all spend a great deal of work-related time together. Consequently, it is only natural that extra-curricular activities are frequently arranged and lasting friendships are often developed. Indeed, in responding to the questionnaire that was distributed for the purposes of Section IV of this article, many former clerks indicated that the most rewarding aspect of their year at the Court was personal, rather than professional.

\section{CONCLUSION}

Now in its third decade, the clerkship program at the Supreme Court of Canada clearly is a success. While it is easy to overstate the matter, some credit for the institution's current level of efficiency must be attributed to the clerks' presence. Access to trained research assistants eases the burdens placed on the judges and improves the quality of justice delivered by the bench. Moreover, the program is successful on a personal level. A year at the Court provides an unparalleled opportunity to witness the judicial enterprise behind the scenes and at its highest level. The lessons to be learned are incalculable and the rewards to be gained are invaluable. It is hoped that this article will encourage all qualified candidates to offer their services to the Court. 